\title{
P-glycoprotein expression in oral lichen planus
}

\begin{abstract}
Abhishek JANA $^{(a)}$ Jimcy THOMAS(b) Pratiti GHOSH ${ }^{(c)}$
\end{abstract}

(a)PMS College of Dental Science \& Research, Department of Physiology, Kerala, India.

(b)PMS College of Dental Science \& Research, Department of Oral Medicine \& Radiology, Kerala, India.

(c)West Bengal State University, Department of Physiology, Kolkata, India.
Declaration of Interest: The authors certify that they have no commercial or associative interest that represents a conflict of interest in connection with the manuscript.

\section{Corresponding Author:}

Pratiti Ghosh

pratitighosh@hotmail.com

htpps://doi.org/10.1590/1807-3107BOR-2017.vol31.0095

Submitted: Apr 14, 2017

Accepted for publication: Sep 11, 2017

Last revision: Oct 05, 2017

\begin{abstract}
Oral lichen planus (OLP) is a stress induced inflammatory condition with malignant potency. The $m d r 1$ (multidrug resistance) is a stress gene overexpressed in cancerous conditions and its translated form, the p-glycoprotein efflux transporter is usually overexpressed with chemotherapy, leading to chemoresistance. OLP, a lesion with carcinogenic potency, is broadly classified into the asymptomatic reticular form and the aggressive erosive form. The objective of the study was to verify the expression level of p-glycoprotein in antifungaltreated and untreated reticular OLP, in untreated erosive OLP and erosive OLP patients treated with corticosteroid. Semi-quantitative reverse transcriptase polymerase chain reaction (SQ-RTPCR) and ELISA were performed on biopsy tissue samples to evaluate the $m d r 1$ mRNA and protein expression of p-glycoprotein, respectively. The present study shows for the first time that $m d r 1$ mRNA as well as its translated form p-glycoprotein are overexpressed in OLP subjects compared to healthy individuals. This overexpression is significantly higher in erosive than in reticular OLP patients, further confirming that the erosive form has higher risk for multidrug resistance. A higher expression is also observed in corticosteroid-treated erosive cases than similar untreated ones. The gradation of expression is in conformity with severity of the disease.
\end{abstract}

Keywords: Lichen Planus, Oral; P-Glycoprotein; Reticular, Erosive, Corticosteroid

\section{Introduction}

Oral lichen planus (OLP) is a mouth lesion affecting the systemic homeostasis. Lichen planus is a common immune-mediated disease that can affect the skin and/or mucous membranes. ${ }^{1}$ The oral form of lichen planus is more frequent than the cutaneous form and tends to be more persistent and resistant to treatment. ${ }^{2}$ Among the six different types of OLP, the reticular type is the most common asymptomatic lesion and the erosive form is the second most common symptomatic lesion having malignant potential in the general population. ${ }^{3}$ Based on the severity of the lesion, corticosteroids are the most commonly used group of drugs for the treatment of OLP. ${ }^{4}$ However, as there is no curative therapy for OLP, 5 the long-term application of topical steroids can lead to development of secondary candidiasis, which needs antifungal therapy. ${ }^{6}$ 
P-glycoprotein, the translated product of $m d r 1$ (multidrug resistance gene 1), is an ATPdependent efflux transporter, and its overexpression is a determinant of multidrug resistance (MDR) phenomenon that occurs during tumor chemotherapy or against environmental toxicants. ${ }^{7}$ It is one of the important drug transporter proteins that determine the uptake and efflux of a wide range of drugs. Its overexpression in tumor cells is associated with reduced access of the cytotoxic drugs $^{7}$ to the diseased cells and is thus expressed minimally in organs with excretory functions such as small intestine, liver, kidney, and also at bloodtissue barriers (blood-brain barrier, blood-testis barrier and placenta). ${ }^{8}$ P-glycoprotein functionality, protein expression and mRNA expression are influenced by a number of xenobiotics ${ }^{9}$ or endogenous compounds. ${ }^{10}$ Pathological conditions, such as infection or inflammation, also may alter the expression of p-glycoprotein, ${ }^{11}$ which is involved in the regulation of apoptosis, stress, cellular immune response or plasma-membrane dynamics. ${ }^{12}$ The expression of p-glycoprotein is also partly determined by ethnicity ${ }^{13}$ and single nucleotide polymorphisms. ${ }^{14}$

To date, there is no report on the expression of p-glycoprotein in OLP, but a significant increase in p-glycoprotein immunopositivity has been observed in similar precancerous lesions. For example, p-glycoprotein levels are associated with severity of dysplasia, across normal, leukoplakia, primary oral squamous cell carcinoma (OSCC) and recurrent OSCC groups ${ }^{15}$. This efflux transporter has also been known to contribute to steroid resistance, ${ }^{16}$ the main drugs for OLP treatment. Furthermore, the possible overexpression of p-glycoprotein in OLP can indicate that if the lesion becomes malignant the treatment by chemotherapy might be undermined.

Therefore, we aimed for the first time to describe the expression level of p-glycoprotein in untreated reticular (mild) and erosive (aggressive) OLP conditions. The expression level in treated erosive OLP (with antifungals and corticosteroids), was also assessed, though antifungals are not expected to enhance $m d r 1$ quantitatively.

\section{Methodology}

\section{Chemicals and reagents}

All the chemicals and gene-specific primers used were from Sigma chemicals and Invitrogen.

\section{Patient selection}

OLP was diagnosed by clinical evaluation and confirmed by histological examination based on clinical criteria defined by WHO.${ }^{17}$ Five newly diagnosed untreated reticular OLP patients and 10 erosive OLP patients, aged 35-55 years were enrolled for this study. Five of the erosive OLP patients were under treatment with clotrimazole (antifungal) and triamcinolone acetonide (synthetic corticosteroid) for one year, and had significant recurrence. The other 5 were untreated erosive OLP patients. Ten age- and sex-matched healthy individuals free from communicable and non-communicable diseases were recruited as control subjects. Exclusion criteria was history of chewing or smoking tobacco, history of alcohol consumption, asthma, hypertension, diabetes, cardiac disorder, bleeding or clotting disorders, psychiatric illness, hepatitis, AIDS, and malignant disease. This project was approved by the Institutional Ethical Committee (IEC No: PMS/IEC/2012/24) of PMS College of Dental Science and Research, India.

\section{Collection of biopsy samples}

Tissue samples were collected from 5 untreated reticular OLP, 5 untreated erosive OLP, 5 treated OLP patients and 5 normal healthy subjects by incisional biopsy. The samples from normal subjects were discarded tissues from normal surgical treatments for impacted teeth.

\section{Semi-quantitative RT-PCR analysis}

To assess the expression level of $m d r 1 \mathrm{mRNA}$ in the two types of OLP, untreated or treated, the transcription was analyzed through semi-quantitative RT-PCR. RNA was isolated from each lesion sample using TRIzol reagent (Life Technology) and mRNA expression was determined using glyceraldehyde-3-phosphate dehydrogenase (GAPDH) as a housekeeping gene to establish the baseline against which the expression of the target gene was compared. The RT-PCR primer sequences 
were 5'AAAGGGAAATTTGGAATTCAGAAAT-3' and 5-'TTGTGCTCTTCCCACAGCCACTGTTT-3' for human $m d r 1$ gene and 5'-GAAGGTGAAGGTCGGAGTC-3' and 5'-GAAGATGGTGATGGGATTTC-3' for human GAPDH gene. The PCR products for each sample were observed on stained gel using E-gel imager system (Invitrogen) and analyzed by Image J Analysis software.

\section{Enzyme-linked immunosorbent assay (ELISA)}

One hundred microliters homogenate of each tissue sample was added to a 96-well plate, incubated at 37 ${ }^{\circ} \mathrm{C}$ overnight. After being washed twice with PBS, samples were incubated for 1 hour at room temperature (RT) with $200 \mu$ of blocking buffer and then washed with PBS TWEEN. Monoclonal p-glycoprotein (100 $\mu \mathrm{L})$ was added and reincubated for 2 hours at RT. Secondary antibody $(100 \mu \mathrm{L})$ was added, mixed and reincubated for 1 hour at RT. After rewashing with PBS TWEEN, $200 \mu \mathrm{L}$ of chromogen (O-phenyl diamine and O-dianizilin) was added and incubated in dark for $30 \mathrm{~min}$ at RT. The reaction was stopped by adding $5 \mathrm{~N} \mathrm{HCl}(50 \mu \mathrm{L})$ and the absorbance read at $405 \mathrm{~nm}$.

\section{Statistical analysis}

Statistical analyses were performed using one-way ANOVA and Student's t-test withSPSS software. Results were considered significantly different at $p<0.05$.

\section{Results}

Molecular biology analyses were performed after confirmation of OLP by histological and clinical evaluation $^{18}$ (Table 1 and Figure 1).

SQ-RTPCR analysis showed that the $m d r 1$ RNA expression level was significantly higher $(p<0.0001)$ in all OLP samples compared to normal samples. The untreated erosive group showed significantly higher $(p<0.05)$ expression of $m d r 1$ compared to untreated reticular group. Highly elevated $(p<0.0001)$ expression of $m d r 1$ was observed in treated erosive group patients compared to untreated erosive group (Figure 2).

ELISA results also showed that expression of p-glycoprotein is significantly elevated ( $p<0.0001)$ in all OLP groups (untreated and treated) compared to healthy individuals, reported as the average of five
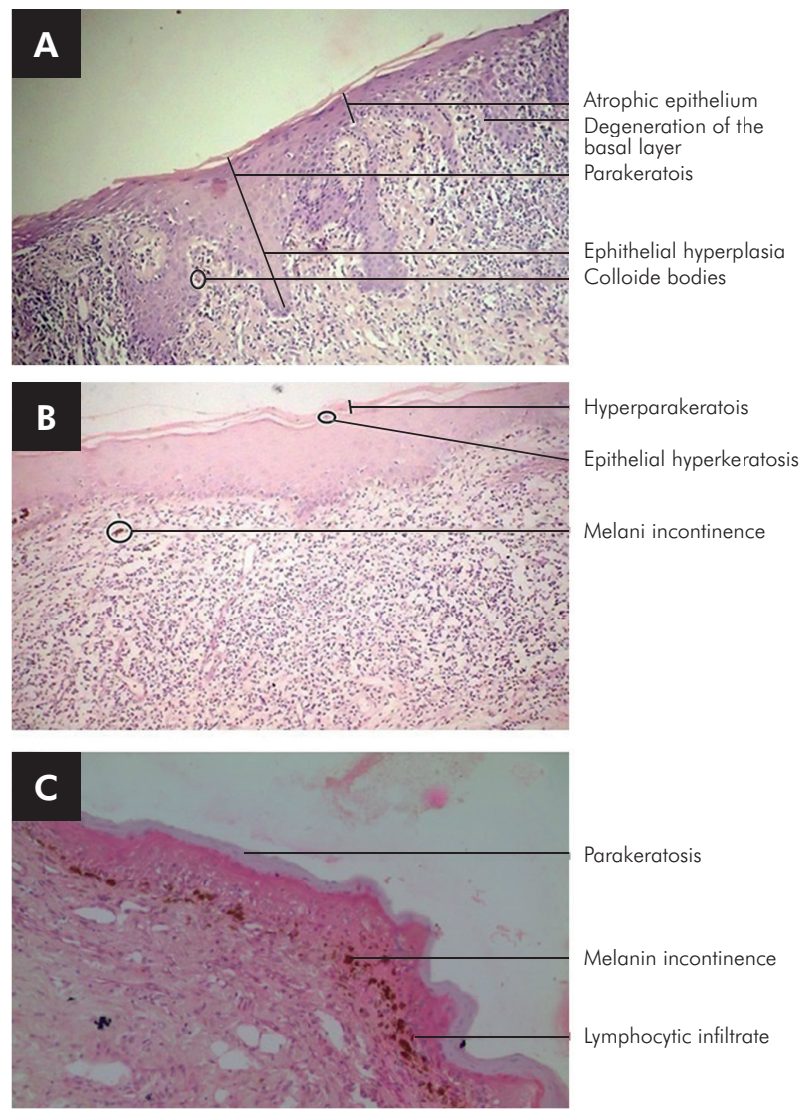

Figure 1. Histological features: (A) In reticular oral lichen planus, parakeratinized stratified squamous epithelium is in association with inflamed fibrovascular connective tissue, the epithelium is atrophic in few foci exhibiting basal cell degeneration, connective tissue shows sub-epithelial band of chronic inflammatory cell infiltrate. (B) In untreated erosive oral lichen planus, hyperparakeratinized stratified squamous epithelium is in association with inflamed fibrovascular connective tissue, the epithelium is atrophic and exhibits basal cell degeneration, the connective tissue shows sub-epithelial band of chronic inflammatory cell infiltrate. (C) In treated erosive oral lichen planus, the epithelium is parakeratinized and exhibits basal cell degeneration, inflammatory lymphocyte infiltration and melanin incontinence.

tissue samples of each type. Significant overexpression $(p<0.05)$ of $p$-glycoprotein was observed in the erosive group compared to the reticular group. Corticosteroid-treated erosive group showed higher $(p<0.03)$ expression of $p$-glycoprotein when compared to untreated erosive group. Thus, both the experiments confirm the increased $m d r 1$ expression and its translation into p-glycoprotein, thus enhancing its functionality with increased severity of the disease as well as with steroid exposure (Figure 3). 
Table 1. Oral lichen planus (OLP) patients enrolled for molecular biology analysis (patient reports).

\begin{tabular}{|c|c|c|c|c|c|}
\hline Variable & Age and sex & Site of lesion & Histological Findings & Clinical appearance & Complications \\
\hline \multicolumn{6}{|c|}{ Reticular OLP (Untreated) } \\
\hline Case No. 1 & $\begin{array}{c}35 \text { years, } \\
\text { female }\end{array}$ & Buccal mucosa & $\begin{array}{c}\text { Subepithelial lymphocytic infiltrate, } \\
\text { epithelial hyperkeratosis, hydropic } \\
\text { degeneration of the basal layer, } \\
\text { atrophic epithelium. }\end{array}$ & $\begin{array}{l}\text { Wickham's striae are bilateral } \\
\text { on buccal mucosa. }\end{array}$ & Painless \\
\hline Case No. 2 & $\begin{array}{c}39 \text { years, } \\
\text { female }\end{array}$ & Tongue & $\begin{array}{l}\text { Subepithelial lymphocytic } \\
\text { infiltrate, epithelial hyperplasia, } \\
\text { melanin incontinence. }\end{array}$ & Same on tongue. & Painless \\
\hline Case No. 3 & $\begin{array}{l}26 \text { years, } \\
\text { female }\end{array}$ & Buccal mucosa & $\begin{array}{l}\text { Hydropic degeneration of the basal } \\
\text { layer, subepithelial lymphocytic } \\
\text { infiltrate, parakeratosis. }\end{array}$ & Same on buccal mucosa. & Painless \\
\hline Case No. 4 & 28 years, male & Buccal mucosa & $\begin{array}{l}\text { Hydropic degeneration of the basal } \\
\text { layer, epithelial hyperkeratosis, } \\
\text { melanin incontinence. }\end{array}$ & Same on buccal mucosa. & Painless \\
\hline Case No. 5 & 42 years, male & Gingiva & $\begin{array}{c}\text { Epithelial hyperplasia, hydropic } \\
\text { degeneration of the basal layer, } \\
\text { parakeratosis, colloid bodies, } \\
\text { atrophic epithelium. }\end{array}$ & Same on gingiva. & Painless \\
\hline \multicolumn{6}{|c|}{ Erosive OLP (Untreated) } \\
\hline Case No. 1 & $\begin{array}{l}29 \text { years, } \\
\text { female }\end{array}$ & Buccal mucosa & $\begin{array}{l}\text { Hyperparakeratosis, subepithelial } \\
\text { lymphocytic infiltrate, melanin } \\
\text { incontinence, epithelial hyperkeratosis. }\end{array}$ & Ulcerated appearance. & Episodic pain \\
\hline Case No. 2 & $\begin{array}{l}45 \text { years, } \\
\text { female }\end{array}$ & Gingiva & $\begin{array}{l}\text { Hydropic degeneration of the basal } \\
\text { layer, melanin incontinence, epithelial } \\
\text { hyperplasia, max-joseph space. }\end{array}$ & $\begin{array}{l}\text { Ulcerated areas surrounded by } \\
\text { keratotic striae. }\end{array}$ & Severe pain \\
\hline Case No. 3 & $\begin{array}{l}52 \text { years, } \\
\text { female }\end{array}$ & Buccal mucosa & $\begin{array}{c}\text { Hydropic degeneration of the basal } \\
\text { layer, subepithelial lymphocytic infiltrate, } \\
\text { orthokeratosis, atrophy. }\end{array}$ & $\begin{array}{c}\text { Erythematous and ulcerated } \\
\text { appearance. }\end{array}$ & Episodic pain \\
\hline Case No. 4 & $\begin{array}{c}37 \text { years, } \\
\text { male }\end{array}$ & Tongue & $\begin{array}{l}\text { Hydropic degeneration of the basal } \\
\text { layer, subepithelial lymphocytic infiltrate, } \\
\text { epithelial hyperkeratosis, colloid bodies. }\end{array}$ & $\begin{array}{l}\text { Mix of erythematous and } \\
\text { ulcerated areas surrounded by } \\
\text { keratotic striae. }\end{array}$ & Severe pain \\
\hline Case No. 5 & $\begin{array}{l}45 \text { years, } \\
\text { male }\end{array}$ & Gingiva & $\begin{array}{l}\text { Subepithelial lymphocytic infiltrate, } \\
\text { atrophy, parakeratosis. }\end{array}$ & Ulcerated appearance. & Severe pain \\
\hline \multicolumn{6}{|c|}{ Erosive OLP (After treatment) } \\
\hline Case No. 1 & $\begin{array}{l}43 \text { years, } \\
\text { female }\end{array}$ & Tongue & $\begin{array}{l}\text { Hydropic degeneration of the } \\
\text { basal layer, parakeratosis, melanin } \\
\text { incontinence, colloid bodies, } \\
\text { epithelial hyperkeratosis. }\end{array}$ & $\begin{array}{l}\text { Ulcerated areas surrounded by } \\
\text { radiating keratotic striae. }\end{array}$ & Severe pain \\
\hline Case No. 2 & $\begin{array}{l}48 \text { years, } \\
\text { female }\end{array}$ & Buccal mucosa & $\begin{array}{l}\text { Hydropic degeneration of the basal } \\
\text { layer subepithelial lymphocytic infiltrate, } \\
\text { melanin incontinence, parakeratosis. }\end{array}$ & Ulcerated appearance. & Severe pain \\
\hline Case No. 3 & $\begin{array}{l}42 \text { years, } \\
\text { female }\end{array}$ & Gingiva & $\begin{array}{c}\text { Epithelial hyperplasia, subepithelial } \\
\text { lymphocytic infiltrate, mild dysplasia, } \\
\text { serrated ridges. }\end{array}$ & $\begin{array}{c}\text { Erythematous and ulcerated } \\
\text { appearance. }\end{array}$ & Severe pain \\
\hline Case No. 4 & $\begin{array}{l}31 \text { years, } \\
\text { male }\end{array}$ & Buccal mucosa & $\begin{array}{l}\text { Subepithelial lymphocytic infiltrate, } \\
\text { hydropic degeneration of the basal layer, } \\
\text { atrophy, colloid bodies, hyperplasia. }\end{array}$ & $\begin{array}{l}\text { Ulcerated areas surrounded by } \\
\text { keratotic striae. }\end{array}$ & Severe pain \\
\hline Case No. 5 & $\begin{array}{c}38 \text { years, } \\
\text { male }\end{array}$ & Gingiva & $\begin{array}{c}\text { Subepithelial lymphocytic infiltrate, } \\
\text { serrated ridges hydropic degeneration of } \\
\text { the basal layer, epithelial hyperkeratosis, } \\
\text { mild dysplasia. }\end{array}$ & $\begin{array}{l}\text { Mix of erythematous and } \\
\text { ulcerated areas surrounded by } \\
\text { keratotic striae. }\end{array}$ & Severe pain \\
\hline
\end{tabular}




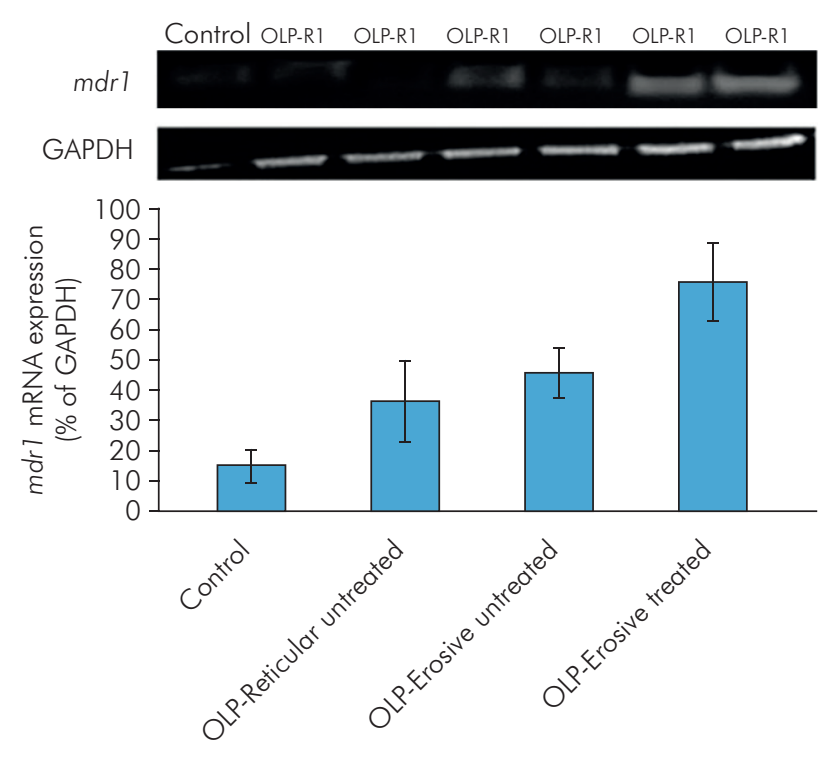

Type of tissue sample

Figure 2. The upper panel shows the expression of $\mathrm{mdr} 7$ mRNA through SQ-RTPCR. The analysis shows that expression levels are significantly higher $(p<0.0001)$ in any OLP tissue compared to the healthy group. The untreated erosive group shows significantly higher $(p<0.05)$ expression of $\mathrm{mdr} 7$ compared to untreated reticular group, and treated erosive group patients had elevated $(p<0.0001$ ) expression of mdrlwas compared to the untreated group. (OLP-R: Oral lichen planus reticular type; OLP-E: Oral lichen planus erosive type; OLP-ET: Oral lichen planus erosive - treated).

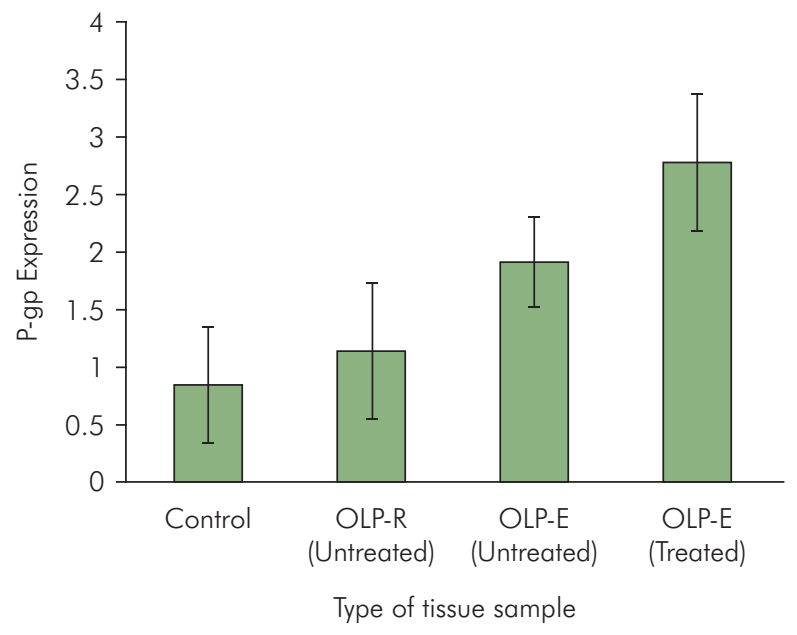

Figure 3. ELISA results show that expression of $p$-glycoprotein $(\mathrm{P}-\mathrm{gp})$ is higher $(\mathrm{p}<0.0001)$ in all OLP groups compared to the control group. Significant overexpression of P-gp ( $p<$ 0.05 ) was observed in the untreated erosive group compared to reticular group. The corticosteroid-treated erosive group shows significantly higher $(\mathrm{p}<0.03)$ expression of $\mathrm{P}$-gp compared to untreated erosive group. (OLP-R: Oral lichen planus reticular type; OLP-E: Oral lichen planus erosive type; OLP-ET: Oral lichen planus erosive treated).

\section{Discussion}

P-glycoprotein is known to be maximally active in cancer, tuberculosis, AIDS and malaria conditions even without exposure to chemotherapeutic drugs. The $m d r 1$ RNA and p-glycoprotein expression are also often enhanced in response to other therapeutic agents such as steroids. The cells sense the presence of such chemicals as a potential threat of the prevailing homeostasis and therefore increase the levels of transporters for the removal of the foreign substances. Corticosteroid treatment has been observed to modulate $\mathrm{p}$-glycoprotein expression in rheumatoid arthritis, ${ }^{16}$ inflammatory bowel disease, ${ }^{19}$ systemic lupus erythematosus ${ }^{20}$ and other conditions. ${ }^{21,22}$ Azole antifungals such as itraconazole and ketoconazole have also been observed to induce p-glycoprotein activity ${ }^{23}$ in a whole cell assay; however, a significant effect has not been observed in any clinical study.

Here, patient selection was based on the assumption that expression of p-glycoprotein is normally present in the oral mucosa, and should increase with the increased severity of the disease from reticular to erosive OLP, and from untreated cases to treated ones. The probability to find elevated levels of the protein is related to the $1-2 \%$ probability of OLP to undergo malignant transformation. We did not evaluate treated and untreated reticular OLP as this form of the disease subsides with treatment. We found here that the OLP patients with milder disease severity (reticular form) showed higher expressions of p-glycoprotein than normal subjects but lower than patients with erosive OLP, which resembled the levels found in malignant conditions. The patients with corticosteroid treatment for the previous six months had higher p-glycoprotein levels than those without treatment.

Induction of p-glycoprotein expression is considered a response to cancer process or to xenobiotic exposure. The expression of p-glycoprotein in all types of OLP samples is a novel step towards identifying the disease as having potency for multidrug resistance, as disease severity and the exposure to steroid treatment increase the expression levels similar to those found in oral squamous cell carcinoma. 


\section{Conclusion}

We thus conclude that the expression of the multidrug resistance marker p-glycoprotein is observed in OLP precancerous lesion, and the levels are higher in the more severe erosive form compared to the reticular form. The multidrug resistance propensity is further enhanced in the corticosteroidtreated erosive tissues than in the untreated tissues.

\section{References}

1. Dudhia BB, Dudhia SB, Patel PS, Jani YV. Oral lichen planus to oral lichenoid lesions: evolution or revolution. J Oral Maxillofac Pathol. 2015;19(3):364-70. https://doi.org/10.4103/0973-029X.174632

2. Mollaoglu N. Oral lichen planus: a review. Br J Oral Maxillofac Surg. 2000;38(4):370-7. https://doi.org/10.1054/bjom.2000.0335

3. Rajendran R. Oral lichen planus. J Oral Maxillofac Pathol. 2005;9(1):3-5. https://doi.org/10.4103/0973-029X.39050

4. Lo Muzio L, Valle A, Mignogna MD, Pannone G, Bucci P, Bucci $E$ et al. The treatment of oral aphthous ulceration or erosive lichen planus with topical clobetasol propionate in three preparations: a clinical and pilot study on 54 patients. J Oral Pathol Med. 2001;30(10):611-7. https://doi.org/10.1034/j.1600-0714.2001.301006.x

5. Lavanya N, Jayanthi P, Rao UK, Ranganathan K. Oral lichen planus: an update on pathogenesis and treatment. J Oral Maxillofac Pathol. 2011;15(2):127-32. https://doi.org/10.4103/0973-029X.84474

6. Vincent SD, Fotos PG, Baker KA, Williams TP. Oral lichen planus: the clinical, historical and therapeutic features of 100 cases. Oral Surg Oral Med Oral Pathol. 1990;70(2):165-71. https://doi.org/10.1016/0030-4220(90)90112-6

7. Thiebaut F, Tsuruo T, Hamada H, Gottesman MM, Pastan I, Willingham MC. Cellular localiszation of the multidrugresistance gene product P-glycoprotein in normal human tissues. Proc Natl Acad Sci U S A. 1987;84(21):7735-8. https://doi.org/10.1073/pnas.84.21.7735

8. Fromm MF. Importance of P-glycoprotein at blood-tissue barriers. Trends Pharmacol Sci. 2004;25(8):423-9. https://doi.org/10.1016/i.tips.2004.06.002

9. Dantzig AH, Alwis DP, Burgess M. Considerations in the design and development of transport inhibitors as adjuncts to drug therapy. Adv Drug Deliv Rev. 2003;55(1):133-50. https://doi.org/10.1016/S0169-409X(02)00175-8

10. Sukhai M, Piquette-Miller M. Regulation of the multidrug resistance genes by stress signals. J Pharm Pharm Sci. 2000;3(2):268-80
As sequential analysis of disease progression was not possible in this study, it is yet unknown whether p-glycoprotein is a cause or an effect of the disruption of the transcription factors network.

\section{Acknowledgement}

The authors would like to thank the Dr. Rajesh Ramachandran and Biogenix Research Center for the enormous support for this study.
11. Fernandez C, Buyse M, German-Fattal M. Influence of the pro-inflammatory cytokines on P-glycoprotein expression and functionality. J Pharm Pharm Sci. 2004;7(3):359-71.

12. Callaghan R, Crowley E, Potter S, Kerr ID. P-glycoprotein: so many ways to turn it on. J Clin Pharmacol. 2008;48(3):365-78. https://doi.org/10.1177/0091270007311568

13. Uematsu T, Hasegawa T, Hiraoka BY, Komatsu F, Matsuura T, Yamada AS et al. Multidrug resistance gene 1 expression in salivary gland adenocarcinomas and oral squamous-cell carcinomas. Int J Cancer. 2001;92:187-94. https://doi.org/10.1002/10970215(200102)9999:9999<::AID-IJC1180>3.0.CO;2-T

14. Sauna ZE, Kim IW, Ambudkar SV. Genomics and the mechanism of P-glycoprotein (ABCB1). J Bioenerg Biomembr. 2007;39(5-6):481-7. https://doi.org/10.1007/s10863-007-9115-9

15. Ralhan R, Narayan M, Salotra P, Shukla NK, Chauhan SS. Evaluation of P-glycoprotein expression in human oral oncogenesis: correlation with clinicopathological features. Int J Cancer. 1997;72(5):728-34. https://doi.org/10.1002/ (SICI)1097-0215(19970904)72:5<728::AID-IJC4>3.0.CO;2-U

16. Maillefert JF, Maynadie M, Tebib JG, Aho S, Walker P, Chatard $\mathrm{C}$ et al. Expression of the multidrug resistance glycoprotein 170 in the peripheral blood lymphocytes of rheumatoid arthritis patients: the percentage of lymphocytes expressing glycoprotein 170 is increased in patients treated with prednisolone. Br J Rheumatol. 1996;35(5):430-5. https://doi.org/10.1093/rheumatology/35.5.430

17. Meij EH, Waal I. Lack of clinicopathologic correlation in the diagnosis of oral lichen planus based on the presently available diagnostic criteria and suggestions for modifications. J Oral Pathol Med. 2003;32(9):507-12. https://doi.org/10.1034/i.1600-0714.2003.00125.x

18. Jana A, Ghosh P. Altered haematological profile of oral lichen planus patients. Res J Pharm Biol Chem Sci. 2014;5(5):1271-7.

19. Farrell RJ, Murphy A, Long A, Donnelly S, Cherikuri A, $\mathrm{O}^{\prime}$ Toole D et al. High multidrug resistance (P-glycoprotein $170)$ expression in inflammatory bowel disease patients who fail medical therapy. Gastroenterology. 2000;118(2):279-88. https://doi.org/10.1016/S0016-5085(00)70210-1 
20. Kansal A, Tripathi D, Rai MK, Agarwal V. Persistent expression and function of P-glycoprotein on peripheral blood lymphocytes identifies corticosteroid resistance in patients with systemic lupus erythematosus. Clin Rheumatol. 2016;35(2):341-9. https://doi.org/10.1007/s10067-015-3079-7

21. Ueda K, Okamura N, Hirai M, Tanigawara Y, Saeki T, Kioka $\mathrm{N}$ et al. Human P-glycoprotein transports cortisol, aldosterone, and dexamethasone, but not progesterone. J Biol Chem. 1992;267(34):24248-52.
22. Crowe A, Tan AM. Oral and inhaled corticosteroids: differences in P-glycoprotein (ABCB1) mediated efflux. Toxicol Appl Pharmacol. 2012;260(3):294-302. https://doi.org/10.1016/i.taap.2012.03.008

23. Wang EJ, Lew K, Casciano CN, Clement RP, Johnson WW. Interaction of common azole antifungals with P glycoprotein. Antimicrob Agents

Chemother. 2002;46(1):160-5.

https://doi.org/10.1128/AAC.46.1.160-165.2002 